\title{
PEMANFAATAN GAMBUT RAWA PENING SEBAGAI PUPUK ORGANIK BRIKET DAN PENGARUHNYA TERHADAP PERTUMBUHAN BATANG BAWAH TANAMAN KARET
}

\author{
Utilization of Rawa Pening Peat as Organic Fertilizer Briquette and Its Effects on \\ The Growth of Rubber Plant Rootstock
}

Riko Cahya PUTRA* dan Titik WIDYASARI

Balai Penelitian Getas, Pusat Penelitian Karet

Jalan Pattimura KM 6, Salatiga, Jawa tengah

*Email: riko_cahya90@yahoo.com

Diterima : 16 Maret 2018 / Disetujui : 30 Mei 2018

\begin{abstract}
Fertilization is an important factor in the activities of rubber plant nursery. One way to improve the effectiveness of inorganic fertilizer is by giving organic fertilizer of Rawa Pening peat. The purpose of this study was to determine the combination of applied inorganic fertilizer and organic fertilizer briquettes of Rawa Pening peat to the growth of rubber rootstock. The research was done at Getas Research Centre Experimental Field, Central Java. The research used a completely randomized block design with 6 treatments and 5 replications. The treatments consisted of 1) control, 2) single fertilizer $N, P, K$ 3) single fertilizer $N, P, K+1$ tablet organic fertilizer, 4) single fertilizer $N, P, K+2$ tablets organic fertilizer, 5) single fertilizer $N+1$ tablet organic fertilizer, 6) single fertilizer $N+2$ tablets organic fertilizer. Result showed that the treatment of single fertilizer $N, P, K$ or only single fertilizer $N$ combined with organic fertilizer briquettes could improved the growth of plant height, stem diameter, and plant wet weight compared with control and treatment of single fertilizer $N, P, K$. Treatment of single fertilizer $N+2$ tablets organic fertilizer was the treatment showing the highest Relative Agronomic Effectiveness (RAE) with a fairly affordable fertilizer cost of IDR 634/tree.
\end{abstract}

Keywords: Growth; organic fertilizer briquettes; Rawa Pening peat; rubber nursery

\begin{abstract}
Abstrak
Pemupukan merupakan faktor penting dalam kegiatan pembibitan tanaman karet. Salah satu cara untuk meningkatkan efektivitas pemupukan anorganik adalah dengan pemberian pupuk organik. Salah satu sumber pupuk organik yang cukup besar adalah endapan gambut dari Rawa Pening. Penelitian ini bertujuan untuk mengetahui pengaruh pemberian pupuk organik briket Rawa Pening yang dikombinasikan dengan pupuk anorganik tunggal terhadap pertumbuhan batang bawah tanaman karet. Penelitian dilakukan di kebun percobaan Balai Penelitian Getas, Jawa Tengah. Rancangan penelitian menggunakan Rancangan Acak Kelompok Lengkap terdiri atas 6 perlakuan dengan 5 ulangan. Perlakuan tersebut adalah, 1) Kontrol (perlakuan tanpa pupuk), 2) pupuk tunggal N, P, K, 3) pupuk tunggal N, P, K + pupuk organik briket 1 tablet, 4) pupuk tunggal $\mathrm{N}, \mathrm{P}, \mathrm{K}+$ pupuk organik briket 2 tablet, 5) pupuk tunggal $\mathrm{N}+$ pupuk organik briket 1 tablet, 6) pupuk tunggal $N+$ pupuk organik briket 2 tablet. Hasil penelitian menunjukkan bahwa perlakuan pupuk tunggal N, P, K atau pupuk tunggal N yang dikombinasikan dengan pupuk organik briket Rawa Pening dapat meningkatkan pertumbuhan tinggi tanaman, diameter batang, dan bobot basah tanaman dibandingkan dengan kontrol dan perlakuan pupuk tunggal N, P, K. Hal tersebut
\end{abstract}


menunjukkan bahwa pemberian pupuk organik gambut Rawa Pening mampu meningkatkan efektivitas pemupukan anorganik. Perlakuan pupuk tunggal $\mathrm{N}+2$ tablet pupuk organik briket Rawa Pening menunjukkan efektivitas agronomi relatif (RAE) tertinggi dengan biaya pupuk yang cukup terjangkau yaitu IDR 634/pohon.

Katakunci: Gambut rawa pening; pem bibitan karet; pertumbuhan; pupuk organik briket

\section{PENDAHULUAN}

Tanaman Karet (Hevea brasiliensis Muell Arg) merupakan tanaman perkebunan yang penting baik dalam ekonomi masyarakat maupun sumber penghasilan bagi negara. Menurut Damanik (2012) diperkirakan pada tahun 2025, sasaran untuk menjadi produsen utama karet dunia akan tercapai dengan areal perkebunan karet Indonesia mencapai 4,5 juta $\mathrm{Ha}$ dan mampu menghasilkan 3,3 juta ton. Potensi produktivitas perkebunan karet di Indonesia yang saat ini diperkirakan dapat mencapai $2.000 \mathrm{Kg} / \mathrm{Ha} /$ tahun masih belum dapat tercapai. Hal tersebut dikarenakan sebagian besar merupakan tanaman tua dan kurang intensifnya pengelolaan kebun. Salah satu langkah yang harus dilakukan untuk meningkatkan produktivitas perkebunan karet adalah dengan memperbaiki bahan tanam atau bibit.

Mengingat pentingnya bibit dalam menentukan perbaikan pembangunan perkebunan karet, maka usahatani pembibitan perlu dikelola dengan baik (Purwati, 2013). Menurut Boerhendhy dan Amypalupy (2011) penyiapan bibit yang kurang tepat sering pula menjadi faktor penyebab lambatnya masa matang sadap sehingga produktivitas tanaman rendah. Kegiatan pembibitan tanaman karet memerlukan media tanam terutama tanah yang subur. Tanah merupakan media yang mempunyai fungsi baik sebagai media tempat berdirinya tanaman maupun sebagai tempat hara yang dibutuhkan tanaman. Pada umumnya tanah subur untuk media pembibitan ketersediaannya semakin menurun sehingga harus menggunakan tanah yang kurang subur (Sianipar, Saputra
\& Puspita, 2014). Kualitas tanah dapat diperbaiki dengan menambahkan pupuk dan atau bahan lain ke tanah (Meihana \& Rusidi, 2013).

Pupuk merupakan kunci dari kesuburan tanah karena berisi satu atau lebih unsur untuk menggantikan unsur yang telah diabsorsi oleh tanaman. Pemupukan berarti menambah unsur hara ke dalam tanah (Lingga \& Marsono, 2010). Tanaman membutuhkan unsur hara yang seimbang dan cukup tersedia di dalam tanah. Jika terjadi kekurangan hara maka pertumbuhan tanaman akan terhambat dan mengalami defisiensi hara tertentu (Parnata, 2004). Dalam kaitan dengan upaya perbaikan kualitas pembibitan tanaman karet, peranan teknologi pemupukan menjadi sangat penting. Pupuk yang banyak digunakan pada pembibitan tanaman karet adalah pupuk anorganik N, P, dan K.

Hal yang perlu untuk diperhatikan dalam kegiatan pemupukan adalah efektivitasnya. Salah satu masukan ke dalam tanah yang dapat meningkatkan efektivitas pemupukan anorganik adalah pupuk organik. Menurut Yuniwati, Iskarima, dan Padulemba (2012) pupuk organik mampu meningkatkan efisiensi penyerapan unsur hara tanaman. Pupuk anorganik tidak dapat menggantikan fungsi pupuk organik karena memiliki peran yang berbeda. Pupuk anorganik berperan menyediakan nutrisi dalam jumlah yang besar bagi tanaman. Pupuk organik berperan menjaga fungsi tanah agar unsur hara dalam tanah mudah dimanfaatkan oleh tanaman, termasuk yang disediakan oleh pupuk anorganik. Pemberian pupuk organik pada tanah juga dapat mengubah dan memperbaiki sifat-sifat tanah, baik fisik, kimia dan biologi tanah.

Salah satu sumber bahan organik yang dapat dimanfaatkan sebagai pupuk organik untuk pembibitan tanaman karet adalah gambut. Gambut merupakan tanah dengan bahan organik yang relatif tebal, selalu tergenang air dan biasanya ditemukan di daerah rawa-rawa yang terus menerus tergenang (Hardjowigeno, 2007). Salah satu sumber bahan gambut yang terdapat di Provinsi Jawa Tengah dengan luas antara 1.770 sampai 2.770 Ha adalah Rawa Pening (Sittadewi, 2008). Produksi 
biomassa eceng gondok sebagai sumber gambut di Rawa Pening sangat tinggi, mencapai 20 sampai $30,5 \mathrm{Kg} / \mathrm{m}^{2}$ atau 200 sampai 300 ton/Ha (Sittadewi, 2007).

Penggunaan gambut untuk media atau pupuk pada pembibitan tanaman biasanya dilakukan dengan cara dicampur langsung. Salah satu bentuk aplikasi pupuk organik selain dengan penggunaan secara langsung tersebut adalah dengan metode pemadatan atau briket. Pupuk briket lebih mudah dalam aplikasi karena tidak harus dicampur dengan media tanam terlebih dahulu. Penelitian ini bertujuan untuk mengetahui pengaruh pemberian pupuk organik briket Rawa Pening yang dikombinasikan dengan pupuk anorganik tunggal terhadap pertumbuhan batang bawah tanaman karet.

\section{BAHAN DAN METODE}

Penelitian dilakukan di kebun percobaan Balai Penelitian Getas, Salatiga, Jawa Tengah pada bulan Februari sampai Oktober 2016. Penanaman dilakukan pada tanggal 29 Februari 2016. Bahan tanam yang digunakan adalah bibit karet klon RRIC 100 berumur 2 bulan. Tanah inceptisols yang digunakan sebagai media tanam memiliki sifat yang ditampilkan pada Tabel 1. Media tanam dimasukkan ke dalam polibeg dengan ukuran polibeg sebesar 25 $\mathrm{cm} \times 30 \mathrm{~cm}$. Pupuk yang digunakan adalah pupuk anorganik tunggal N (Urea), P (SP36), $\mathrm{K}(\mathrm{KCl})$ dan pupuk organik briket Rawa Pening.

Pembuatan pupuk briket dimulai dengan pengomposan gambut Rawa Pening yang berasal dari endapan enceng gondok. Pengomposan dilakukan dengan penambahan EM4 sebagai dekomposer. Bahan didekomposisikan selama satu bulan dengan melakukan pengendalian suhu dan kelembaban. Pengendalian suhu dan kelembaban dapat dilakukan dengan cara pembalikan bahan kompos dan atau penyiraman setiap satu minggu sekali. Bahan hasil pengomposan kemudian dipadatkan menggunakan alat yang didesain khusus. Pupuk organik briket Rawa Pening yang dihasilkan memiliki diameter bawah $5 \mathrm{~cm}$ dan tinggi $7 \mathrm{~cm}$ dengan

Tabel 1. Hasil analisa media tanam

Table 1. Results of planting media analysis

\begin{tabular}{|c|c|c|}
\hline $\begin{array}{c}\text { Jenis penetapan } \\
\text { Type of determination }\end{array}$ & $\begin{array}{c}\text { Hasil penetapan } \\
\text { Results of determination }\end{array}$ & $\begin{array}{l}\text { Kriteriä } \\
\text { Criteria }\end{array}$ \\
\hline Tektur & Lempungan & \\
\hline Pasir (\%) & 13,15 & \\
\hline Debu $(\%)$ & 34,10 & \\
\hline Lempung (\%) & 52,75 & \\
\hline $\mathrm{pH} \mathrm{H}_{2} \mathrm{O}$ & 5,25 & Masam \\
\hline \multicolumn{3}{|l|}{ Bahan organik } \\
\hline C (\%) & 0,91 & Sangat rendah \\
\hline N (\%) & 0,11 & Rendah \\
\hline $\mathrm{C} / \mathrm{N}$ & 8,27 & Rendah \\
\hline $\mathrm{P}_{2} \mathrm{O}_{5}$ Bray I (ppm) & 5,58 & Rendah \\
\hline \multicolumn{3}{|l|}{ Kation dapat ditukar } \\
\hline $\mathrm{K}(\mathrm{me} / 100 \mathrm{~g})$ & 0,52 & Sedang \\
\hline $\mathrm{Ca}(\mathrm{me} / 100 \mathrm{~g})$ & 1,25 & Sangat rendah \\
\hline Mg (me/100 g) & 0,30 & Sangat rendah \\
\hline $\mathrm{Na}$ (me/100g) & 0,10 & Sangatrendah \\
\hline KTK (me/ $100 \mathrm{~g})$ & 15,73 & Rendah \\
\hline KB (\%) & 13,79 & Sangat rendah \\
\hline
\end{tabular}

Sumber (Source): Achmad dan Putra (2016)

Keterangan (Remaks): " pengharkatan menurut Balai Penelitian Tanah (2009) 
kisaran berat 90 sampai $100 \mathrm{~g}$ (Gambar 1) dengan sifat kimia yang ditampilkan pada Tabel 2.

Rancangan percobaan yang digunakan adalah Rancangan Acak Kelompok Lengkap (Randomize Completely Block Design), terdiri atas enam perlakuan dengan setiap perlakuan diulang sebanyak lima kali. Perlakuan terdiri atas: 1) kontrol (perlakuan tanpa pupuk); 2) pupuk tunggal $\mathrm{N}, \mathrm{P}, \mathrm{K} ; 3)$ pupuk tunggal $\mathrm{N}, \mathrm{P}, \mathrm{K}+$ pupuk organik briket 1 tablet; 4) pupuk tunggal
$\mathrm{N}, \mathrm{P}, \mathrm{K}+$ pupuk organik briket 2 tablet; 5 ) pupuk tunggal $\mathrm{N}+$ pupuk organik briket 1 tablet; 6) pupuk tunggal $\mathrm{N}+$ pupuk organik briket 2 tablet.Dosis rekomendasi pupuk tunggal anorganik disajikan pada Tabel 3. Pupuk anorganik tunggal diberikan dengan cara ditugal di sekeliling tanaman dengan jarak $10 \mathrm{~cm}$ dari pangkal batang dengan kedalaman sekitar $5 \mathrm{~cm}$. Pupuk organik briket dimasukan ke dalam polibeg dengan posisi di tengah-tengah dan dilakukan pada saat pengisian media tanam.



Gambar 1. Pupuk organik briket gambut Rawa Pening Figure 1. Organic fertilizer briquettes of Rawa Pening peat

Tabel 2. Hasil analisa pupuk briket organik Rawa Pening Table 2. Result of organic fertilizer of Rawa Pening peat briquettes analysis

\begin{tabular}{lc}
\hline $\begin{array}{c}\text { Jenis penetapan } \\
\text { Type of determination }\end{array}$ & $\begin{array}{c}\text { Hasil penetapan } \\
\text { Results of determination }\end{array}$ \\
\hline $\mathrm{pH} \mathrm{H} \mathrm{H}_{2} \mathrm{O}$ & 5,74 \\
C-Organik (\%) & 29,98 \\
N Total $(\%)$ & 1,02 \\
C / N & 29,39 \\
P Total $(\%)$ & 1,74 \\
K Total $(\%)$ & 0,96 \\
KTK $(\mathrm{me} / 100 \mathrm{~g})$ & 90,78 \\
\hline
\end{tabular}

Tabel 3. Dosis rekomendasi pupuk tunggal N, P, K pada pembibitan batang bawah karet di polibeg

Table 3. Recommendation dosage of single fertilizer rubber plants in nursery rootstock polybag

\begin{tabular}{ccccc}
\hline $\begin{array}{c}\text { Umur } \\
\text { (bulan) }\end{array}$ & \multicolumn{3}{c}{$\begin{array}{c}\text { Dosis pupuk tunggal (g/pohon) } \\
\text { Single fertilizer dosage (g/tree) }\end{array}$} \\
\cline { 2 - 5 } $\begin{array}{c}\text { Age } \\
\text { (months) }\end{array}$ & Urea & SP 36 & $\mathrm{KCl}$ & $\begin{array}{c}\text { Frekuensi pemupukan } \\
\text { Fertilization frequency }\end{array}$ \\
\hline 2 & 5 & 4 & 2 & $1 \mathrm{kali} / \mathrm{bln}$ \\
3 & 5 & 4 & 2 & $1 \mathrm{kali} / \mathrm{bln}$ \\
4 & 5 & 4 & 5 & $1 \mathrm{kali} / \mathrm{bln}$ \\
5 & 10 & 5 & 10 & $1 \mathrm{kali} / \mathrm{bln}$ \\
6 & 10 & 5 & & kali/bln \\
\hline
\end{tabular}


Pengamatan pertumbuhan tanaman dilakukan setiap bulan sekali selama lima bulan. Parameter pertumbuhan yang diamati terdiri atas : (1) tinggi tanaman dengan cara mengukur tanaman dari bagian tanaman di atas tanah sampai ujung titik tumbuh bagian atas yang berbentuk seperti huruf "V" menggunakan meteran, (2) diameter batang di ukur dari bagian tanaman di atas tanah dengan ketinggian 10 $\mathrm{cm}$ menggunakan digital microcaliper. Pada akhir percobaan juga dihitung bobot basah (tanaman dan akar) dengan ditimbang dengan menggunakan timbangan analitik dan bobot kering diperoleh dari pengovenan suhu $105^{\circ} \mathrm{C}$ selama 24 jam.

Analisis tanah dan pupuk organik rawa pening menggunakan metode analisis menurut Balai Penelitian Tanah (2009). Sifat kimia dan fisika tanah media tanam dianalisis terdiri atas : tekstur 3 fraksi; $\mathrm{pH}$ ekstrak $\mathrm{H}_{2} \mathrm{O}$; C-organik; $\mathrm{N}$ total; $\mathrm{P}$ tersedia Bray; nilai tukar kation $\mathrm{Ca}, \mathrm{Mg}, \mathrm{K}$ dan $\mathrm{Na}$ ekstrak $\mathrm{NH}_{4}-\mathrm{Ac} 1 \mathrm{~N}$ pH7; dan kapasitas tukar kation (KTK). Analisis pupuk organik Rawa Pening terdiri atas : $\mathrm{pH}$ dengan ekstrak $\mathrm{H}_{2} \mathrm{O}$; C-organik; $\mathrm{N}$ total; $\mathrm{P}$ total; $\mathrm{K}$ total; dan kapasitas tukar kation (KTK).

Untuk mengetahui pengaruh perlakuan, data dianalisis dengan Analisis Sidik Ragam (ANOVA) dan diikuti dengan uji lanjutan menggunakan Duncan Multiple Range Test (DMRT) pada taraf 5\% untuk melihat perbedaan antar perlakuan. Untuk mengetahui efektivitas kombinasi pupuk anorganik tunggal dan pupuk organik briket Rawa Pening dianalisis dengan RAE atau efektivitas agronomi relatif (Relative Agronomic Effectiveness) menggunakan rumus sebagai berikut:

$\operatorname{RAE}(\%)=\frac{Y p-Y k}{Y a-Y k} \times 100$

Keterangan (Remaks) :

RAE : Efektivitas Agronomi Relatif (relative Agronomic Effectiveness)

Yp : Hasil yang diperoleh dari aplikasi pupuk organik briket yang diuji

Yk : Hasil yang diperoleh tanpa pemberian pupuk (perlakuan kontrol)

Ya : Hasil yang diperoleh dari aplikasi pupuk acuan (perlakuan pupuk NPK)
Selain itu juga dilakukan analisis perbandingan biaya pupuk. Menurut Suratiyah (2016) yang menyatakan bahwa :

Biaya total $=\mathrm{FC}+\mathrm{VC}$

Keterangan (Remaks) :

$\mathrm{FC}=$ Biaya tetap (IDR)

$\mathrm{VC}=$ Biaya variabel (IDR)

Oleh karena semua perlakuan hanya berbeda di jenis pupuk yang digunakan, dan tidak berpengaruh kepada penggunaan biaya tetap dan biaya variabel lainnya, maka yang diperbandingkan hanya harga dan jumlah pupuk yang dipergunakan. Asumsi dalam analisis biaya pupuk sebagai berikut:

a. Harga pupuk Urea : IDR $5.200 / \mathrm{Kg}$ (sumber N)

b. Harga pupuk SP36 : IDR $5.400 / \mathrm{Kg}$ (sumber P)

c. Harga pupuk KCl : IDR $5.700 / \mathrm{Kg}$ (sumber K)

d. Harga pupuk : : IDR $2.000 / \mathrm{Kg}$ organik briket $\quad(1 \mathrm{Kg}=10$ tablet $)$

e.Jumlah pupuk yang digunakan menyesuaikan dengan perlakuan (satuan g)

\section{HASIL DAN PEMBAHASAN}

\section{Media Tanam}

Berdasarkan kriteria kesuburan tanah, hasil analisis tanah inceptisol yang digunakan sebagai media tanam menunjukkan kandungan hara $\mathrm{N}, \mathrm{P}$, dan $\mathrm{K}$ tergolong sangat rendah hingga sedang. Ketersediaan hara menjadi permasalahan utama kesuburan tanah inceptisol. Menurut Munir (1996) tanah inceptisol memerlukan masukan hara yang tinggi melalui pemupukan berimbang terutama untuk hara makro $\mathrm{N}, \mathrm{P}$, dan $\mathrm{K}$.

Media tanah yang digunakan memiliki kapasitas tukar kation (KTK) tergolong rendah dan bahan organik tergolong sangat rendah. Tanah yang memiliki KTK dan kandungan bahan organik yang rendah menyebabkan tingkat efektivitas pemupukan menjadi rendah karena unsur hara kation dalam tanah 
mudah tercuci dari komplek pertukaran. Tingkat efisiensi pemupukan yang rendah menyebabkan pertumbuhan dan produktivitas tanaman menjadi tidak optimal. Penelitian Herviyanti, Fachri, Darmawan, Gusnidar, dan Amrizal (2012) menyatakan bahwa tanah dengan kandungan bahan organik tinggi dapat meningkatkan jumlah muatan negatif yang menyebabkan KTK tanah tinggi dan mampu mengikat unsur hara dengan baik, sehingga efektivitas pemupukan anorganik juga meningkat. Menurut Arviandi, Rauf, dan Sitanggang (2015) kandungan bahan organik dalam bentuk C-organik di tanah harus dipertahankan tidak kurang dari $2 \%$ untuk dapat menjaga kesuburan kimia, fisika maupun biologi tanah. Kandungan bahan organik sangat erat berkaitan dengan KTK (Kapasitas Tukar Kation) tanah. Upaya yang diperlukan untuk memperbaiki kesuburan tanah tersebut adalah melalui pemberian pupuk organik.

\section{Pupuk Organik Briket Gambut Rawa Pening}

Kandungan C-organik pupuk organik briket Rawa Pening sebesar 29,98\% atau setara $51,68 \%$ bahan organik. Berdasarkan penelitian Purnomo, Soedarsono, dan Putri (2013) kandungan bahan organik Rawa Pening berkisar antara $61,99 \%$ sampai $69,90 \%$ dengan $\mathrm{pH}$ agak masam. Menurut Rosmarkam dan Yuwono (2002) kandungan bahan organik di atas $35 \%$ tergolong kandungan bahan organik yang sangat tinggi. Kandungan hara N, P, dan $\mathrm{K}$ pupuk organik berturut-turut adalah $1,02 \%, 1,74 \%$, dan $0,96 \%$ dengan KTK sebesar 90,78 me/100g.

\section{Tinggi Tanaman}

Hasil pengukuran tinggi tanaman selama lima bulan ditampilkan pada Tabel 4. Pada pengamatan terakhir bulan Juli menunjukkan bahwa perlakuan pupuk tunggal $\mathrm{N}, \mathrm{P}, \mathrm{K}$ atau pupuk tunggal $\mathrm{N}$ yang dikombinasikan dengan pupuk organik briket 2 tablet menunjukkan hasil yang berbeda nyata dibandingkan kontrol. Perlakuan pupuk Tunggal N + pupuk organik briket 2 tablet merupakan perlakuan yang menunjukkan hasil yang berbeda nyata dibandingkan kontrol dan perlakuan pupuk tunggal N, P, K. Laju pertumbuhan tinggi tanaman tertinggi pada perlakuan pupuk tunggal $\mathrm{N}+$ pupuk organik briket 2 tablet sebesar 85,2 $\mathrm{cm}$ dengan peningkatan $75,67 \%$ dibandingkan kontrol dan $66,60 \%$ dibandingkan perlakuan pupuk tunggal $\mathrm{N}, \mathrm{P}, \mathrm{K}$. Hal tersebut sesuai dengan penelitian Sari, Sudrajat, dan Sugiyanta (2015), bahwa kombinasi antara pupuk organik dan anorganik mampu meningkatkan rerata pertumbuhan tinggi tanaman bibit kelapa sawit dibandingkan perlakuan pupuk anorganik tanpa pemberian pupuk organik karena bahan organik mampu memperbaiki kondisi tanah sehingga unsur hara lebih tersedia.

\section{Diameter Batang}

Hasil pengukuran diameter batang selama lima bulan ditampilkan pada Tabel 5. Pengamatan terakhir pada bulan Juli menunjukkan laju pertumbuhan diameter batang pada perlakuan pupuk tunggal N, P, $\mathrm{K}$ atau pupuk tunggal $\mathrm{N}$ yang dikombinasikan dengan pupuk organik briket berbeda nyata dibandingkan kontrol

Tabel 4. Pertumbuhan tinggi tanaman

Table 4. Plant height growth

\begin{tabular}{|c|c|c|c|c|c|}
\hline \multirow[t]{2}{*}{$\begin{array}{l}\text { Perlakuan } \\
\text { Treatments }\end{array}$} & \multicolumn{5}{|c|}{$\begin{array}{l}\text { Tinggi tanaman } \\
\text { Plant height } \\
(\mathrm{cm})\end{array}$} \\
\hline & $28 \mathrm{Mar}$ & 26 Apr & 26 Mei & 27 Jun & $28 \mathrm{Jul}$ \\
\hline Kontrol, tanpa pemupukan & $11,82 \mathrm{a}$ & $21,14 a$ & $33,96 a$ & $41,78 \mathrm{a}$ & $48,50 \mathrm{a}$ \\
\hline Pupuk tunggal N,P,K & $13,84 a b$ & $25,28 \mathrm{ab}$ & $39,98 \mathrm{ab}$ & $47,80 \mathrm{a}$ & $51,14 \mathrm{ab}$ \\
\hline Pupuk tunggal $\mathrm{N}, \mathrm{P}, \mathrm{K}+$ pupuk organik briket 1 tablet & $18,38 \mathrm{ab}$ & $29,64 a b$ & $45,00 b$ & $50,26 a b$ & $63,18 \mathrm{ab}$ \\
\hline Pupuk tunggal N,P,K + pupuk organik briket 2 tablet & $17,22 \mathrm{ab}$ & $30,12 b$ & $47,74 b$ & $54,64 a b$ & $68,94 \mathrm{bc}$ \\
\hline Pupuk tunggal $\mathrm{N}+$ pupuk organik briket 1 tablet & $20,31 b$ & $32,30 \mathrm{~b}$ & $43,48 a b$ & $50,28 \mathrm{ab}$ & $57,08 \mathrm{ab}$ \\
\hline Pupuk tunggal $\mathrm{N}+$ pupuk organik briket 2 tablet & $17,32 \mathrm{ab}$ & $32,62 b$ & $44,5 b$ & $62,90 \mathrm{~b}$ & $85,20 \mathrm{c}$ \\
\hline
\end{tabular}

Keterangan : huruf berbeda pada kolom sama menunjukkan berbeda nyata

Remaks : different letters in the same column showed significantly different 
dan perlakuan pupuk tunggal N, P, K. Laju pertumbuhan diameter batang tertingggi pada perlakuan pupuk tunggal $\mathrm{N}+$ pupuk organik briket 2 tablet sebesar $8,12 \mathrm{~mm}$ dengan peningkatan $97,57 \%$ dibandingkan kontrol dan 47,37\% dibandingkan perlakuan pupuk tunggal N, P, K. Hal tersebut sesuai dengan penelitian Sari et al. (2015) bahwa pemberian kombinasi pupuk organik dan anorganik menunjukkan diameter batang bibit tanaman kelapa sawit yang lebih tinggi dibandingkan perlakuan pupuk anorganik tanpa pemberian pupuk organik. Menurut Adnan, Utoyo, dan Kusumastuti (2015) pemberian pupuk anorganik dan pupuk organik dapat meningkatkan diameter batang.

Tabel 5. Pertumbuhan diameter batang

Table 5. Stem diameter growth

\begin{tabular}{|c|c|c|c|c|c|}
\hline \multirow[t]{2}{*}{$\begin{array}{l}\text { Perlakuan } \\
\text { Treatments }\end{array}$} & \multicolumn{5}{|c|}{$\begin{array}{c}\text { Diameter batang } \\
\text { Stem diameter } \\
(\mathrm{mm})\end{array}$} \\
\hline & $28 \mathrm{Mar}$ & $26 \mathrm{Apr}$ & 26 Mei & 27 Jun & 28 Jul \\
\hline Kontrol, tanpa pemupukan & $0,51 \mathrm{a}$ & $1,39 \mathrm{a}$ & $2,34 a$ & $3,40 a$ & $4,11 \mathrm{a}$ \\
\hline Pupuk tunggal $N, P, K$ & $0,68 \mathrm{ab}$ & $1,71 \mathrm{ab}$ & $3,32 b$ & $4,73 b$ & $5,51 b$ \\
\hline Pupuk tunggal N,P,K + pupuk organik briket 1 tablet & $1,27 \mathrm{c}$ & $2,25 \mathrm{bc}$ & $3,93 \mathrm{bc}$ & $6,26 c$ & $7,01 \mathrm{~cd}$ \\
\hline Pupuk tunggal N,P,K + pupuk organik briket 2 tablet & $0,97 \mathrm{bc}$ & $2,14 \mathrm{bc}$ & $4,40 \mathrm{~cd}$ & $6,53 c$ & $7,26 \mathrm{~cd}$ \\
\hline Pupuk tunggal $\mathrm{N}+$ pupuk organik briket 1 tablet & $1,02 \mathrm{bc}$ & $2,37 \mathrm{c}$ & $4,00 \mathrm{bc}$ & $5,93 c$ & $6,69 c$ \\
\hline Pupuk tunggal $\mathrm{N}+$ pupuk organik briket 2 tablet & $0,94 b c$ & $2,65 c$ & $5,04 c$ & $7,53 d$ & $8,12 \mathrm{~d}$ \\
\hline
\end{tabular}

Keterangan : huruf berbeda pada kolom sama menunjukkan berbeda nyata

Remaks : different letters in the same column showed significantly different

\section{Bobot Tanaman}

Data bobot basah dan kering tanaman pada akhir penelitian ditampilkan pada Tabel 6. Kombinasi pupuk organik briket dengan pupuk tunggal N, P, K atau pupuk tunggal $\mathrm{N}$ menunjukkan hasil bobot basah dan kering tanaman yang berbeda nyata terhadap kontrol. Perlakuan pupuk tunggal $\mathrm{N}+$ pupuk organik briket 2 tablet merupakan perlakuan dengan bobot basah dan kering tanaman yang berbeda nyata dibandingkan kontrol dan perlakuan pupuk tunggal N, P, K.

Tabel 6. Hasil bobot tanaman

Table 6. Results of plant weight

\begin{tabular}{lcc}
\hline & $\begin{array}{c}\text { Bobot tanaman } \\
\text { Perlakuan } \\
\end{array}$ & $\begin{array}{c}\text { Plant weight } \\
\text { (g) }\end{array}$ \\
\cline { 2 - 3 } & Basah & $\begin{array}{c}\text { Kering } \\
\text { Dry }\end{array}$ \\
\hline Kontrol, tanpa pemupukan & $23,55 \mathrm{a}$ & $9,40 \mathrm{a}$ \\
Pupuk tunggal N,P,K & $73,80 \mathrm{~b}$ & $26,38 \mathrm{~b}$ \\
Pupuk tunggal N,P,K + pupuk organik briket 1 tablet & $89,04 \mathrm{c}$ & $33,46 \mathrm{bc}$ \\
Pupuk tunggal N,P,K + pupuk organik briket 2 tablet & $73,98 \mathrm{~b}$ & $31,14 \mathrm{bc}$ \\
Pupuk tunggal N + pupuk organik briket 1 tablet & $101,42 \mathrm{~d}$ & $31,77 \mathrm{bc}$ \\
Pupuk tunggal N + pupuk organik briket 2 tablet & $113,08 \mathrm{~d}$ & $40,70 \mathrm{c}$ \\
\hline
\end{tabular}

Keterangan : huruf berbeda pada kolom sama menunjukkan berbeda nyata

Remaks : different letters in the same column showed significantly different 
Bobot basah tanaman tertinggi pada perlakuan pupuk tunggal $\mathrm{N}+$ pupuk organik briket 2 tablet sebesar 113,08 g dengan peningkatan 380,17\% dibandingkan kontrol dan 53,23\% dibandingkan perlakuan pupuk tunggal N, P, K. Bobot kering tanaman tertinggi sebesar 40,70 g juga diperoleh pada perlakuan pupuk tunggal $\mathrm{N}+$ pupuk organik briket 2 tablet dengan peningkatan 332,94\% dibandingkan kontrol dan 54,28\% dibandingkan pupuk tunggal N, P, K. Penelitian Adnan et al. (2015) juga menunjukkan hasil bahwa pemberian pupuk anorganik NPK yang dikombinasikan dengan pupuk organik mampu meningkatkan rerata bobot akar bibit kelapa sawit dibandingkan perlakuan pupuk anorganik NPK tanpa pemberian pupuk organik. Unsur hara $\mathrm{N}, \mathrm{P}, \mathrm{K}$ merupakan unsur yang penting dalam proses fotosintesis dan pembentukan organ-organ tanaman (Parnata, 2004).

\section{Bobot Akar}

Data bobot basah dan kering akar pada akhir penelitian ditampilkan pada Tabel 7. Kombinasi pupuk organik briket dengan pupuk tunggal $\mathrm{N}, \mathrm{P}, \mathrm{K}$ atau pupuk tunggal $\mathrm{N}$ menunjukkan hasil bobot basah dan kering akar yang berbeda nyata dibandingkan kontrol. Perlakuan pupuk tunggal $\mathrm{N}+$ pupuk organik briket 2 tablet dan perlakuan pupuk tunggal $\mathrm{N}, \mathrm{P}, \mathrm{K}+$ pupuk organik briket 2 tablet merupakan perlakuan dengan bobot basah dan kering akar yang berbeda nyata dibandingkan kontrol dan perlakuan pupuk tunggal N, P, $\mathrm{K}$.
Bobot basah akar tertinggi pada perlakuan pupuk tunggal $\mathrm{N}, \mathrm{P}, \mathrm{K}+$ pupuk organik briket 2 tablet sebesar 49,74 g dengan peningkatan $179,12 \%$ dibandingkan kontrol dan 18,20\% dibandingkan perlakuan pupuk tunggal N, P, K. Bobot kering akar tertinggi sebesar 18,22 g juga pada perlakuan pupuk tunggal $\mathrm{N}, \mathrm{P}, \mathrm{K}+$ pupuk organik briket 2 tablet dengan peningkatan 170,73\% dibandingkan kontrol dan 25,29\% dibandingkan pupuk tunggal $\mathrm{N}$, $\mathrm{P}, \mathrm{K}$. Unsur $\mathrm{P}$ yang diberikan melalui pemupukan memiliki peran penting untuk pertumbuhan akar tanaman. Menurut Nyakpa (1988) unsur P berperan untuk merangsang perakaran tanaman dan berat kering akar. Akar merupakan faktor penting dalam pertumbuhan tanaman yang mencerminkan kemampuan penyerapan unsur hara dan dapat dimanfaatkan untuk pertumbuhan akar serta metabolisme pada tanaman (Saragih, Sampoerno, \& Islan, 2014).

\section{Efektivitas Agronomi Relatif (RAE)}

RAE dari pemberian pupuk organik briket pada pembibitan batang bawah karet ditampilkan pada Tabel 8. Nilai RAE ditentukan untuk mengetahui efektivitas pupuk organik briket yang diberikan. Perhitungannya RAE didasarkan pada hasil bobot kering total tanaman karet (bobot tanaman dan akar). Perlakuan pupuk tunggal N, P, K merupakan perlakuan yang digunakan sebagai acuan atau pembanding dengan RAE 100\%. Menurut Widiyawati, Sugiyanta, Junaedi, dan Widyastuti (2014) pupuk dinyatakan efektif secara agronomi

Tabel 7. Hasil bobot akar

Table 7. Results of root weight

\begin{tabular}{lcc}
\hline & $\begin{array}{c}\text { Perlakuan } \\
\text { Treatments }\end{array}$ & \multicolumn{2}{c}{$\begin{array}{c}\text { Root weight } \\
\text { (g) }\end{array}$} \\
\cline { 2 - 3 } & Basah & $\begin{array}{c}\text { Kering } \\
\text { Wet }\end{array}$ \\
\hline Kontrol, tanpa pemupukan & $17,82 \mathrm{a}$ & $6,73 \mathrm{a}$ \\
Pupuk tunggal N,P,K & $42,08 \mathrm{~b}$ & $14,51 \mathrm{~b}$ \\
Pupuk tunggal N,P,K + pupuk organik briket 1 tablet & $44,82 \mathrm{bc}$ & $14,20 \mathrm{~b}$ \\
Pupuk tunggal N,P,K + pupuk organik briket 2 tablet & $49,74 \mathrm{c}$ & $18,22 \mathrm{c}$ \\
Pupuk tunggal N + pupuk organik briket 1 tablet & $36,58 \mathrm{~b}$ & $13,64 \mathrm{~b}$ \\
Pupuk tunggal N + pupuk organik briket 2 tablet & $44,50 \mathrm{bc}$ & $18,18 \mathrm{c}$ \\
\hline
\end{tabular}

Keterangan : huruf berbeda pada kolom sama menunjukkan berbeda nyata

Remaks : different letters in the same column showed significantly different 
Tabel 8. Hasil Efektivitas Agrononmi Relatif (RAE)

Table 8. Relative Agronomic Effectiveness (RAE) results

\begin{tabular}{lc}
\multicolumn{1}{c}{$\begin{array}{c}\text { Perlakuan } \\
\text { Treatments }\end{array}$} & $\begin{array}{c}\text { RAE } \\
(\%)\end{array}$ \\
\hline Kontrol, tanpa pemupukan & 0 \\
Pupuk tunggal N,P,K & 100 \\
Pupuk tunggal N,P,K + pupuk organik briket 1 tablet & 127 \\
Pupuk tunggal N,P,K + pupuk organik briket 2 tablet & 134 \\
Pupuk tunggal N + pupuk organik briket 1 tablet & 118 \\
Pupuk tunggal $\mathrm{N}+$ pupuk organik briket 2 tablet & 173 \\
\hline
\end{tabular}

apabila memiliki nilai RAE di atas $100 \%$, yang berarti pupuk tersebut dapat meningkatkan hasil lebih besar dibandingkan dengan peningkatan hasil pupuk pembanding terhadap kontrol. Hasil penelitian ini menunjukkan bahwa pada kombinasi pupuk organik briket dengan pupuk tunggal $\mathrm{N}, \mathrm{P}, \mathrm{K}$ atau pupuk tunggal $\mathrm{N}$ memiliki nilai RAE di atas $100 \%$. Hal tersebut menunjukkan bahwa pupuk anorganik akan lebih efektif apabila dikombinasikan dengan pupuk organik.

Efektivitas agronomi pupuk anorganik yang dikombinasikan dengan pupuk organik briket gambut Rawa Pening berkisar antara $118 \%$ sampai $173 \%$. Penelitian Sari et al. (2015) menunjukkan bahwa kombinasi pupuk anorganik dengan pupuk organik mampu meningkatkan efektivitas agronomi tanaman sebesar $111,4 \%$ sampai $131,4 \%$ dibandingkan perlakuan pupuk anorganik tanpa pemberian pupuk organik pada pembibitan kelapa sawit. Peningkatkan pertumbuhan tanaman dikarenakan bahan organik dapat memperbaiki kondisi tanah sehingga unsur hara lebih tersedia untuk tanaman. Salah satu manfaat dari pupuk organik adalah dapat memperbaiki sifat kimia tanah khususnya meningkatkan kapasitas tukar kation $(\mathrm{KTK})$. KTK tanah tinggi menunjukkan bahwa tanah mampu menjerap dan menyediakan jumlah unsur hara yang lebih tinggi.

Perlakuan yang memiliki efektivitas paling baik atau RAE tertinggi sebesar 173\% pada perlakuan pupuk tunggal $\mathrm{N}$ yang dikombinasikan dengan pupuk organik briket 2 tablet. Hal tersebut dikarenakan pada saat pertumbuhan vegetatif tanaman, unsur $\mathrm{N}$ lebih dibutuhkan tanaman.
Menurut Novizan (2001) nitrogen dibutuhkan untuk membentuk senyawa penting seperti klorofil, asam nukleat dan enzim. Nitrogen dibutuhkan dalam jumlah relatif besar pada setiap tahap pertumbuhan tanaman, khususnya pertumbuhan vegetatif. Penelitian Suharno, Mawardi, Setiabudi, dan Tjitrosemito (2007) juga menunjukkan bahwa penambahan pupuk organik dapat meningkatkan kandungan klorofil daun sehingga meningkatkan pertumbuhan tanaman. Selain itu, kebutuhan unsur $\mathrm{P}$ dan $\mathrm{K}$ untuk pertumbuhan batang bawah tanaman karet juga diperoleh dari pupuk organik briket.

\section{Analisis Biaya Pupuk}

Menurut Ruhnayat (2007) ketidaktepatan pemberian unsur hara selain akan menyebabkan tanaman tidak dapat tumbuh dan berproduksi secara optimal juga merupakan pemborosan biaya. Analisis biaya pupuk dilakukan untuk mengetahui besarnya biaya pupuk antar perlakuan yang ditampilkan dalam Tabel 9. Jika dibandingkan dengan kontrol, biaya tertinggi terdapat di perlakuan pupuk N, P, K + pupuk organik briket 2 tablet, sedangkan yang terendah di perlakuan pupuk tunggal $\mathrm{N}$ + pupuk organik briket 1 tablet. Hal tersebut terjadi karena semakin banyak jenis dan jumlah pupuk yang digunakan mengakibatkan biaya pupuk yang semakin tinggi juga. Namun demikian, berdasarkan analisis agronomis menghasilkan yang terbaik adalah perlakuan pupuk tunggal $\mathrm{N}+$ pupuk organik briket 2 tablet. Perlakuan tersebut jika ditinjau dari biaya pupuknya senilai IDR 634,-/pohon. Biaya pupuk yang cukup rendah dibandingkan dengan perlakuan lainnya namun hasilnya dapat maksimal. Hasil maksimal ditunjukkan 
Tabel 9. Analisis biaya pupuk per pohon Table 9. Analysis of fertilizer cost per tree

\begin{tabular}{lcr}
\hline \multicolumn{1}{c}{$\begin{array}{c}\text { Perlakuan } \\
\text { Treatments }\end{array}$} & Biaya pupuk & $\begin{array}{c}\text { Selisih } \\
\text { biaya* }\end{array}$ \\
\cline { 2 - 3 } & $\begin{array}{c}\text { Fertilizer cost } \\
\text { (IDR) }\end{array}$ & $\begin{array}{c}\text { Cost margin } \\
\text { (\%) }\end{array}$ \\
\hline Kontrol, tanpa pemupukan & 0 & - \\
Pupuk tunggal N,P,K & 574 & 35 \\
Pupuk tunggal N,P,K + pupuk organik briket 1 tablet & 774 & 70 \\
Pupuk tunggal N,P,K + pupuk organik briket 2 tablet & 974 & $(24)$ \\
Pupuk tunggal N + pupuk organik briket 1 tablet & 434 & 11 \\
Pupuk tunggal N + pupuk organik briket 2 tablet & 634 & \\
\hline
\end{tabular}

Keterangan: *) selisih biaya pupuk terhadap perlakuan pupuk N,P,K.

Remaks: *) margin of fertilizer cost to the treatment of straight fertilizer $N, P, K$

dengan nilai tertinggi pada tinggi tanaman, diameter batang, bobot tanaman, bobot akar, dan RAE. Untuk mencapainya, hanya memerlukan tambahan biaya $11 \%$ setiap pohon atau IDR 60,-/pohon terhadap biaya pupuk N, P, K yang akan menghasilkan pertumbuhan tanaman jauh lebih baik.

\section{KESIMPULAN}

Pemberian pupuk tunggal N, P, K atau pupuk tunggal $\mathrm{N}$ yang dikombinasikan dengan pupuk organik briket Rawa Pening mampu meningkatkan pertumbuhan tinggi tanaman, diameter batang, dan bobot basah tanaman dibandingkan dengan kontrol dan perlakuan pupuk tunggal N, P, K. Perlakuan pupuk tunggal $\mathrm{N}+$ pupuk organik briket 2 tablet merupakan perlakuan yang menunjukkan efektivitas agronomi tertinggi dengan RAE sebesar 173\%. Perlakuan tersebut menunjukkan tinggi tanaman, diameter batang, bobot basah tanaman, bobot kering tanaman dan bobot kering akar yang lebih tinggi dan berbeda nyata dibandingkan perlakuan pupuk tunggal $\mathrm{N}$, $\mathrm{P}, \mathrm{K}$. Penggunaannya memerlukan biaya yang cukup terjangkau yaitu IDR 634,/pohon, atau $11 \%$ lebih tinggi daripada hanya menggunakan pupuk tunggal $\mathrm{N}, \mathrm{P}, \mathrm{K}$.

\section{DAFTAR PUSTAKA}

Achmad, R. S., \& Putra, C. R. (2015). Respon tanaman karet di pembibitan terhadap pemberian pupuk majemuk magnesium plus. Jurnal Penelitian Karet, 34(1), 49-60. Doi : 10.22302/ppk.jpk.v34i1.230
Adnan, I. S., Utoyo. B., \& Kusumastuti, A. (2015). Pengaruh pupuk NPK dan pupuk organik terhadap pertumbuhan bibit kelapa sawit di main nursery. Jurnal Agro Industri Perkebunan, 5(21), 69-81. Doi : 10.25181/aip.v3i2.20

Arviandi, R., Rauf. A., \& Sitanggang, G. (2015). Evaluasi sifat kimia tanah inceptisol pada kebun inti tanaman gambir (Uncaria gambir roxb.) di Kecamatan Salak Kabupaten Pakpak Bharat. Jurnal Agroekoteknologi, 3(4), 1329-1334.

Balai Penelitian Tanah. (2009). Petunjuk teknis analisis kimia tanah, tanaman, air, dan pupuk. Bogor, Indonesia: Badan Penelitian dan Pengembangan Pertanian.

Boerhendy, I., \& Amypalupy, A. (2011). Optimalisasi produktivitas karet melalui penggunaan bahan tanam, pemeliharaan, sistem eksploitasi, dan peremajaan tanaman. Jurnal Litbang Pertanian, 30(1), 23-30.

Damanik, S. (2012). Pengembangan karet (Havea brasiliensis) berkelanjutan di Indonesia. Perspektif, 11(1), 91-102.

Hardjowigeno, S. (2007). Klasifikasi tanah dan pedogenesis. Jakarta, Indonesia: Akademika Pressindo. 
Herviyanti, A., Fachri, S., Darmawan, R., Gusnidar., \& Amrizal, S. (2012). Pengaruh pemberian bahan humat dan pupuk $P$ pada Ultisol. Jurnal Solum, 19, $15-24$. Doi : $10.25077 /$ js.9.1.15-24.2012

Lingga, P., \& Marsono. (2010). Petunjuk penggunaan pupuk. Jakarta, Indonesia: Penebar Swadaya.

Meihana \& Rusidi. (2013). Pemanfaatan limbah media jamur tiram sebagai bahan pencampur tanah dan dosis pupuk NPK majemuk bagi pertumbuhan bibit karet setum mata tidur (Hevea brasiliensis Muell Arg.) di polybag. Jurnal Ilmiah AgrIBA, 2(2), 225-236.

Munir, M. (1996). Tanah-tanah utama Indonesia. Jakarta, Indonesia: Pustaka Jaya.

Novizan, (2001). Petunjuk pemupukan yang efektif. Jakarta, Indonesia: Agromedia Pustaka.

Nyakpa, Y. (1988). Kesuburan tanah. Lampung, Indonesia: Universitas Lampung.

Parnata, A. S. (2004). Pupuk organik cair, aplikasi dan manfaatnya. Jakarta, Indonesia: Agromedia Pustaka.

Purnomo, P. W., Soedarsono, P., \& Putri, M. N. (2013). Profil vertikal bahan organik dasar perairan dengan latar belakang pemanfaatan berbeda di Rawa Pening. Jurnal of Management of Aquatic Resources, 2(3), 27-36.

Purwati. (2013). Pertumbuhan bibit karet (Hevea brasiliensis 1.) asal okulasi pada pemberian bokashi dan pupuk organik cair bintang kuda laut. Agrifor, 12(1), 35-44.

Rosmarkam, A., \& Yuwono, N. W. (2002). Ilmu kesuburan tanah. Yogyakarta, Indonesia: Kanisius.
Ruhnayat, A. (2007). Penentuan kebutuhan pokok unsur hara $\mathrm{N}, \mathrm{P}, \mathrm{K}$ untuk pertumbuhan tanaman panili (Vanillaplanifolia). Buletin Penelitian Tanaman rempah dan Obat, 18(1), 4959. Doi : 10.21082/bullittro.v18i1 $.2007 .25 p$

Saragih, N. W., Sampoerno., \& Islan. (2014). Pertumbuhan bibit karet (Hevea brasiliensis) okulasi pada media campuran subsoil dengan pupuk organik. Jurnal Mahasiswa Pertanian, 1(2), 1-12.

Sari, V. I., Sudrajat., \& Sugiyanta. (2015). Peran pupuk organik dalam meningkatkan efektivitas pupuk NPK pada bibit kelapa sawit di pembibitan utama. Jurnal Agronomi Indonesia, $43(2), \quad 153-160$. D o i: 10.24831/jai.v43i2.10422.

Sianipar, S. S. E., Saputra, S. I., \& Puspita, F. (2014). Uji beberapa dosis pupuk hayati mikoriza terhadap pertumbuhan stum mini karet (Hevea brasiliensis). Jurnal Mahasiswa Pertanian, 1(2), 1-11.

Sittadewi, E. H. (2007). Pengelolaan bahan organik enceng gondok menjadi media tumbuh untuk mendukung pertanian organik. Jurnal Teknologi Lingkungan, $8(3), 229-234$. D o i: 10.29122/jtl.v8i3.430

Sittadewi, E. H. (2008). Kondisi lahan pasang surut kawasan Rawa Pening dan potensi pemanfaatannya. Jurnal Teknologi Lingkungan, 9(3), 294-301. Doi : $10.29122 /$ jtl.v9i3.474

Suharno, I., Mawardi, N., Setiabudi, S., \& Tjitrosemito, I. (2007). Efisiensi penggunaan nitrogen pada tipe vegetasi yang berbeda di Taman Nasional Gunung Halimun Jawa Barat. Biodiversitas, 8, 287-294.

Suratiyah, K. (2016). Imu usahatani (edisi revisi). Jakarta, Indonesia: Penebar Swadaya. 
Widiyawati, I., Sugiyanta., Junaedi, A., \& Widyastuti, R. (2014). Peran bakteri penambat nitrogen untuk mengurangi dosis pupuk nitrogen anorganik pada padi sawah. Jurnal Agronomi Indonesia, 42(2), 96-102.
Yuniwati, M., Iskarima, F., \& Padulemba, A. (2012). Optimasi kondisi proses pembuatan kompos dari sampah organik dengan cara fermentasi menggunakan EM4. Jurnal Teknologi, 5(2), 172-181. 